\title{
Purchasing Power Parity in Some African Countries Using a Nonlinear Panel Unit Root Test
}

\author{
Justice Kyei-Mensah \\ Ghana Institute of Management Public Administration (GIMPA)
}

This study investigates further whether the PPP holds between the US and some 22 African countries from $1^{\text {st }}$ January 1980 to $31^{\text {st }}$ December 2018. The results show that we cannot reject the null hypothesis of a unit root in the 14 series of KSS (2003) demeaned, 10 series of Kruse (2011) demeaned, and 20 series of ADF constant, thus series are non-stationary. Similarly, when de-trended of KSS (2003), detrended of Kruse (2011) and constant and trend of ADF tests were run, both linear and nonlinear unit root tests fail to reject null hypothesis almost all the series under study. The results seem to suggest that real exchange rates are non-stationary in these 22 African countries. The Johansen's test result shows that deviations from PPP for 12 of 22 countries are persistent.

Keywords: Purchasing Power Parity, Unit Root Test, Real Exchange Rates, Non-Stationary, African Countries, Johansen Cointegration Test

\section{INTRODUCTION}

Over the year's one of the topics that have been explored by finance and economics researchers is purchasing power parity theory (hereafter PPP), using a linear and nonlinear fashion unit root test. The PPP uses inflation rates to forecast the imminent movements in exchange rates. The PPP states that the nominal exchange rate between two national currencies should be equal to general price levels of the two countries, and then the exchange rates should change to keep the relative price the same. PPP is centred on the law of one price. The law of one price is an economic hypothesis which maintains that a basket of good must sell for the same price in all countries. This law is originated from the notion of the inevitable elimination of all arbitrage. PPP may not hold in the short-run as a result of transaction cost, capital control, imperfect competition and taxation. These reasons can effectively impair the arbitrage process, and as a result, deviations from the PPP many periods. As observed by Pentecost (1993) and Doganlar et al. (2009) the failure of PPP is attributed to many factors such as technology, economic structure, productivity, inflation rates, transportation cost, speculative capital moments, and trade barriers. Nevertheless, PPP may hold in the long-run, for the fact that international goods market arbitrage must remain constant. The mere fact we don't normally observe persistent arbitrage conditions, we can securely assume that PPP holds in the long run. The empirical evidence of the validity of PPP in long run has been provided by Sarno and Taylor (2002), Cheung et al. (2004), Taylor and Taylor (2004), Krogbo (2006), Lothian and Taylor (2008), Arize et al. (2010) and Chang et al. (2012),

The PPP and International Fisher Effect (IFE) are connected, as both use the spot rate and inflation differential to predict future exchange rate (Akinboade and Makina, 2006). The IFE claims that the 
interest rate differentials between the two countries provide an unbiased predictor of future changes in the spot rate of exchange. The IFE assumes that all countries will have the same real interest rate, although nominal or money rates may differ due to expected inflation rates. Thus the interest rate differential between two countries should be equal to the expected inflation rates. The IFE suggests that the nominal interest rate differential reflects the expected change in the exchange rate. For instance, if the interest rate is 3 per cent per year in the US and 13 per cent in South Africa, US dollar is expected to appreciate against the South Africa Rand by 10 per cent per year. These African countries are cauterized by high inflation, exchange rate depreciation, nominal shocks, and trade openness and amongst other things which often led to a swifter adjustment in relative prices and thus seem to proof PPP holds. According to relative purchasing power parity, a currency from a higher inflationary economy will depreciate, relative to the currency of a lower inflationary economy, by approximately the differential of the two countries inflation.

In their studies, Holmes (2001) and Sarno (2005) used the PPP to forecast exchange rate and ascertain whether a currency is overvalued or undervalued which significant for emerging economies. Holmes (2001) second idea of PPP as a foundation of many theories of exchange rate determination is built. He proposed that policymakers in developing countries centred their adjustment on the PPP. Zehirun et al. 2005 employed Johansen's multivariate co-integration technique, based on unit root test, to test the generalized purchasing power parity (GPPP) in Southern African Development Community (SADC) using monthly data, 1995 to 2012, and found that the validity of GPPP holds in SADC region. In the same way, Yilanci et al. (2017) test the validity of PPP in 14 African countries by employing Fourier unit root and cointegration tests in which structural changes for 1980 to 2015 using monthly data. The study found that the PPP holds for 8 out of 14 African countries. Yilanci and Eris (2013) examine the validity of PPP by applying Fourier unit root test proposed by Christopoulos and Leon-Ledesma (2010) that account for the existence of multiple breaks in the real exchange rate. They found that the PPP is valid for 20 out of 35 African countries. In related studies, He et al. (2014) test the PPP by applying Panel KSS unit root test with a Fourier function for 15 Latin American countries and found that the PPP holds for 14 out of 15 Latin American countries, signifies that PPP holds for almost all the countries used in their study. Using the Johansen multivariate co-integration technique on annual data for 1958 to 2003 on black market exchange rates, Krogbo (2006) found empirical support for long-run PPP in 40 African countries. Many studies on testing PPP in Africa countries used conventional unit root test such as the ADF unit root test but such conventional unit root tests have low power in identifying mean reversion of exchange rate (Hamilton, 1994; He et al. 2014), many researchers in testing validity of PPP have resulted in using panel and nonlinear unit root tests. It is well known that time series are normally modelled by linear equations; unit root tests might be biased due to the presence of nonlinearities in the deterministic terms.

Despite numerous empirical studies, there is no consensus on the validity of PPP for African countries. This find may reflect some degree the level of economic instability in the region and possibly the inconsistencies in economic policies. The region has experienced an unprecedented overvalued exchange rates, record increased in the volatility of real exchange rates and depreciation of the national currency. Under these conditions, if the assumptions associated with the estimation approach do not hold, then inferences based on the results may be unreliable. Empirical tests for the stationarity of time series, especially of macroeconomic variables are economically important since a finding of stationarity means that shocks to the variable have a permanent effect on the future path of the variable. Thus, these considerations have motivated us to undertake a study the accounts for potential non-linearity in our PPP tests regarding the non-stationarity of African countries exchange rates. In this study, we used the approach of Kapetanios et al. (2003) which is the extension of Augmented Dickey-Fuller (ADF) test which detects non-stationarity in a time series against a nonlinear but globally stationary exponential smooth transitions autoregressive (ESTAR) process of Granger and Terasvirta (1993). In this model, the transition between economic regimes is presumed to transpire smoothly. We also employed the nonlinear test of Kruse (2011), based on a modified Ward Type test against a nonlinear but globally stationary exponential smooth transitions autoregressive (ESTAR) model.

An alternative method is to check the long-run PPP hypothesis is to conduct the cointegration test of the nominal exchange rates and the foreign and domestic price levels. We use Johansen $(1988,1990)$ 
multivariate cointegration method to test whether the series has a long-run relationship or association ship.

The remainder of the paper is organized as follows: Section 2 describes the data used in the study. Section 3 presents the exponential smooth transitions autoregressive (ESTAR) methodology. Section 4 describes the detailed empirical results. The paper concluded in the final section.

\section{DATA}

This empirical study employs the monthly data on nominal exchange rates against the US dollar and the consumer price indexes (CPI). The series data are obtained from the International Financial Statistics (IFS) of the International Monetary Fund (IMF) website. A sample data of these 22 African countries include Algeria, Burkina Faso, Botswana, Cameroon, Cote d'Ivoire, Egypt, Ethiopia, Gabon, Gambia, Ghana, Kenya, Madagascar, Malawi, Mauritius, Morocco, Nigeria, Niger, Rwanda, Senegal, Seychelles, South Africa, Togo. The sample data span from $1^{\text {st }}$ January 1980 to $31^{\text {st }}$ December 2018. The PPP method measures the real exchange rate as the price of foreign goods relative to the price of domestic goods. The nominal exchange rate and the consumer price index in equation 1 were transformed into natural logarithms before the econometric analysis. Our bilateral real exchange rate is calculated using equation 1 as follows:

$R E R_{i}=\operatorname{In}\left(e_{i}\right)+\operatorname{In}\left(P f_{i}\right)-\operatorname{In}\left(P d_{i}\right)$

where $e_{i}$, is the nominal exchange rate is measured in U.S. dollars per unit of foreign currency, $P f_{i}$ and $P d_{i}$ denote the consumer price indices (CPI $\left.2010=100\right)$ of the foreign country and the domestic country respectively (the US as the base country). Using Eqn. 1, we test the unit root in the real exchange rate, whether the PPP holds or not. We compare Kapetanios et al. (2003 and Kruse (2011 nonlinear unit root test against the linear ADF unit root test. To address the problem of serial correlation in equation (2), appropriate lag structures of the dependent variable were incorporated and ADF test, we select the appropriate lag structures for the Schwartz Information Criterion (SIC).

\section{METHODOLOGY}

\section{Nonlinear Unit Root Test Against ESTAR}

This empirical study used the univariate unit root approach of Kapetanios et al. (2003) which is the extension of Augmented Dickey-Fuller (ADF) test which detects non-stationarity in a time series against a nonlinear but globally stationary exponential smooth transition autoregressive (ESTAR) process of Granger and Terasvirta (1993) in which transitions between regimes is presumed to transpire smoothly. The approach of Kapetanios et al. (2003) test nonlinear unit root test against exponential smooth transition autoregressive (ESTAR) model. Kapetanios et al. (2003) claim that their new test has power over the extant Dickey-fuller tests implies utmost in the region of null. Kapetanios et al. (2003), ESTAR nonlinear but globally stationary process is written as:

$$
\Delta y_{t}=\alpha y_{t-1}+\phi y_{t-1}\left(1-\exp \left\{-\gamma\left(y_{t-1}-c\right)^{2}\right\}\right)+\varepsilon_{t}
$$

is an ESTAR model of first-order, ESTAR first order where $c$ location parameter. Kapetanios et al. show that "under alternative hypothesis $y_{t}$ follow a nonlinear but globally stationary process". Kapetanios et al. (2003) indicate that the ESTAR model under the restriction $\alpha=0$,

$$
\Delta y_{t}=\phi y_{t-1}\left(1-\exp \left\{-\gamma\left(y_{t-1}-c\right)^{2}\right\}\right)+\varepsilon_{t}
$$


is globally stationary if $-2 \phi<<0$ is assumed to hold.

For this reason, in equation (2), Kapetanios et al. (2003) make the restriction $c=0$ and their new model becomes:

$\Delta y_{t}=\phi y_{t-1}\left(1-\exp \left\{-\gamma\left(y_{t-1}-c\right)^{2}\right\}\right)+\varepsilon_{t}$

In equation (4), $y_{t}$ is the demeaned and/or de-trended series. Kapetanios et al. (2003) adopted the first order of Tayl tor series approximation for $\left(1-\exp \left\{-y_{t=1}-c\right\}^{2}\right)$ (the nonlinear adjustment) as auxiliary regression

$\Delta y_{t}=\beta_{1} y_{t-1}^{3}+\varepsilon_{t}$

Kapetanios et al.(2003) t-test of null of a unit root hypothesis against an alternative of a globally stationary nonlinear ESTAR method is $H_{0}: \beta_{1}=0$ versus $H_{1}: \beta_{1}<0$. The unit root test of auxiliary regression (5) and estimating a Dickey-Fuller type $t$-test Kapetanios et al. (2003) (hereafter KSS (2003)) to test

$\operatorname{KSS}(2003)=\frac{\sum_{t=1}^{T} y_{t-1}^{3} \Delta y_{t}}{\sqrt{\hat{\sigma}^{2} \sum_{t=1}^{T} y_{t-1}^{6}}}$

where $\hat{\sigma}^{2}$ is the error variance? A detailed explanation can be found in Kapetanios et al. (2003), Kruse (2011) and Su et al. (2012).

\section{Modified Ward Type Test Against ESTAR}

Kruse (2011) extends the extant test of Kapetanios et al. (2003) unit root test. Kruse (2011) proposed that the location parameter $c$ in the exponential transition function should be nonzero, consider the nonlinear model.

$\Delta y_{t}=\not y_{t-1}\left(1-\exp \left\{-\gamma\left(y_{t-1}-c\right)^{2}\right\}\right)+\varepsilon_{t}$

Kruse (2011) modify Kapatanion et al. (2003) unit root test to deal further with the problem of a standard Wald test would be unsuitable, hence modified Wald test using the process of Abadir and Distaso (2007). He claims the modified Wald test "builds upon the one-sided parameter $\left(\beta_{1}\right)$ and the transformed two-sided parameter, say $\beta \frac{1}{2}$, that are stochastically independent by definition". He finds that his adjusted test-statistics deal much better with the modified Wald test statistic of Abadir and Distaso (2007). For further explanation see Kruse (2011).

\section{EMPIRICAL RESULTS}

The data set for real exchange rates consists of monthly observations of some African countries. Figure 1 indicates the real exchange rates (in natural logarithms) in the time series from 1980M1 to 2018M12. The plots suggest that the real exchange rates series are non-stationary which reveals 
significant upward and or downward trends in most of the countries relative to the US dollar. The nonstationary of the univariate series with a structural break can infer that the series is trend stationary.

\section{FIGURE 1}

THE PLOTS OF RERS FOR 22 AFRICAN COUNTRIES RELATIVE TO US DOLLAR

\section{RER of Algeria}

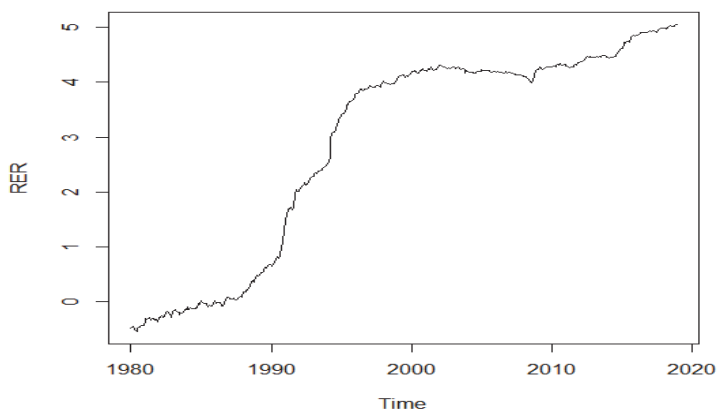

RER of Botswana

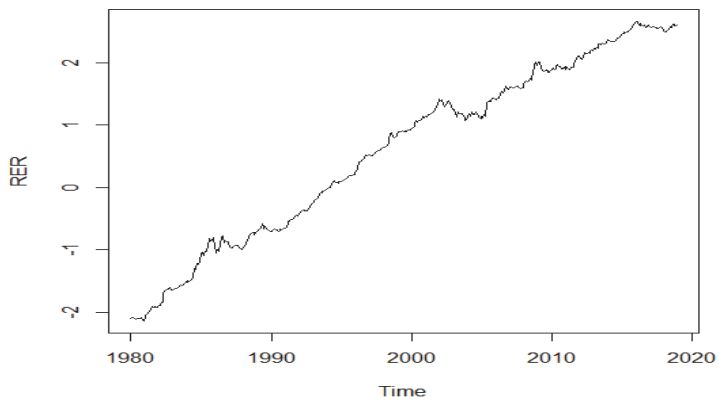

RER of Cote d'Ivoire

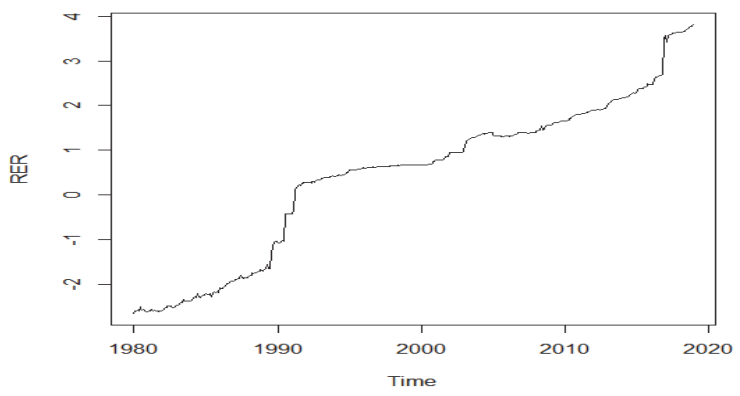

RER of Burkina Faso

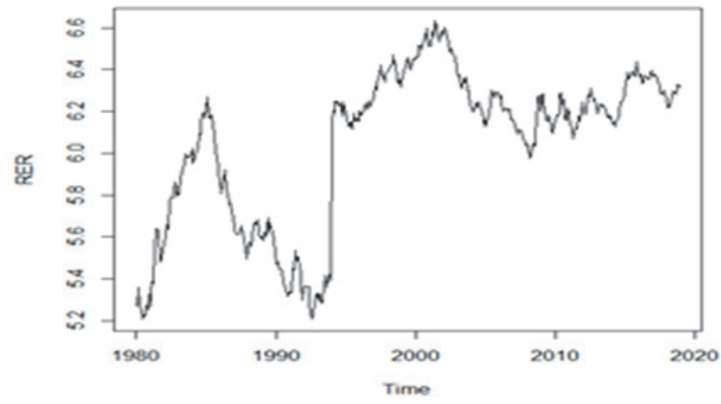

RER of Cameroon

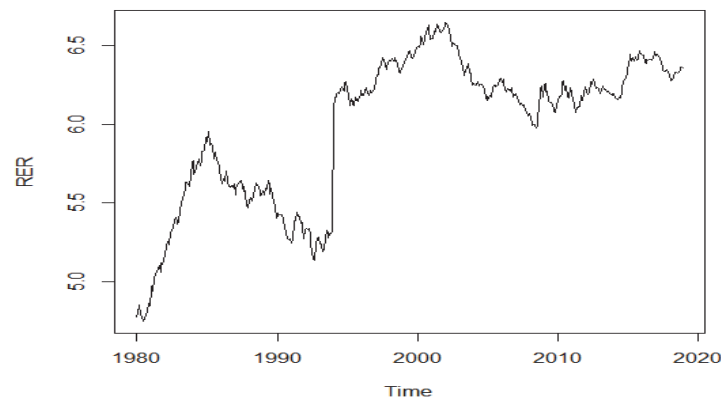

RER of Egypt

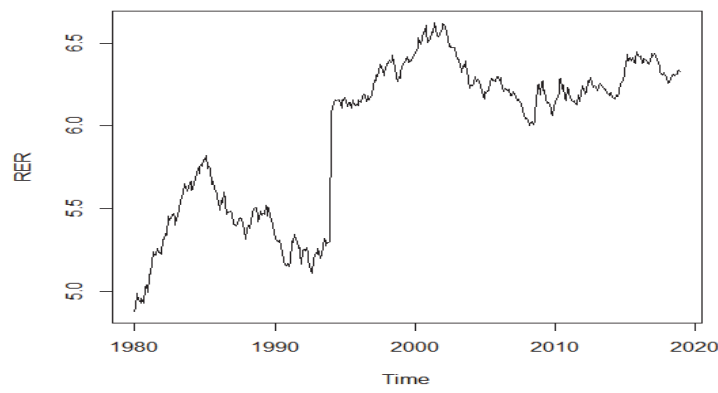


RER of Ethiopia

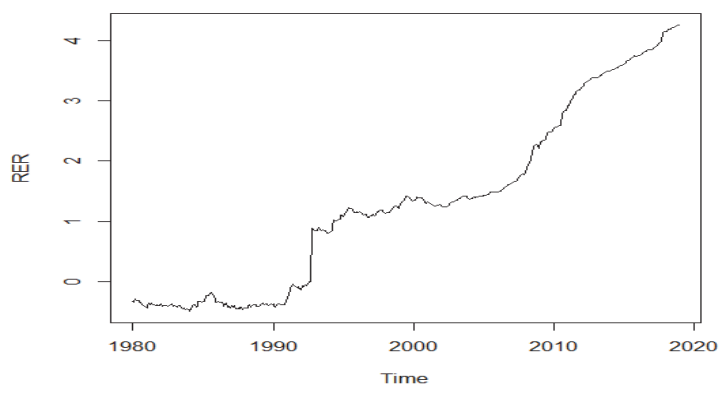

RER of Gambia

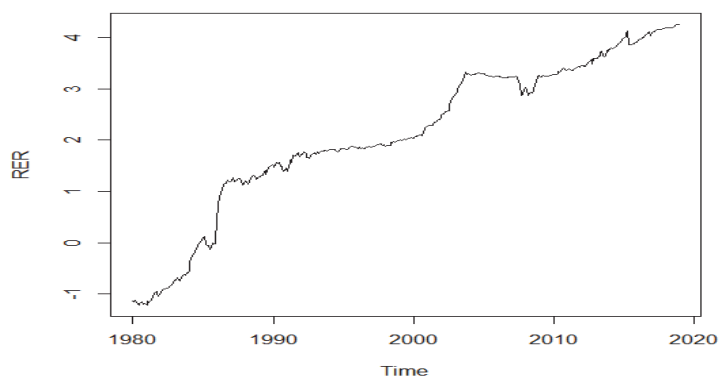

RER of Kenya

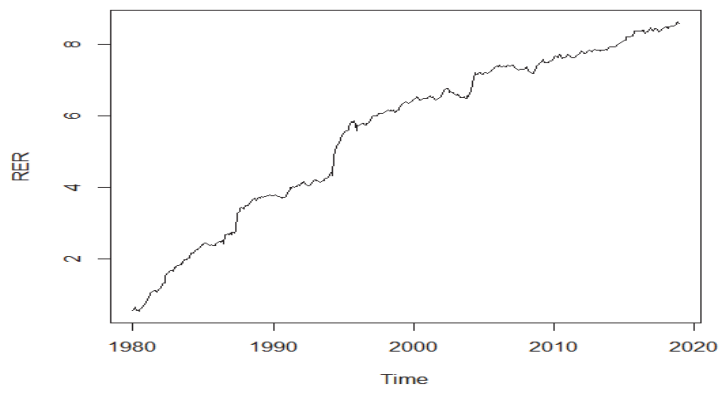

RER of Malawi

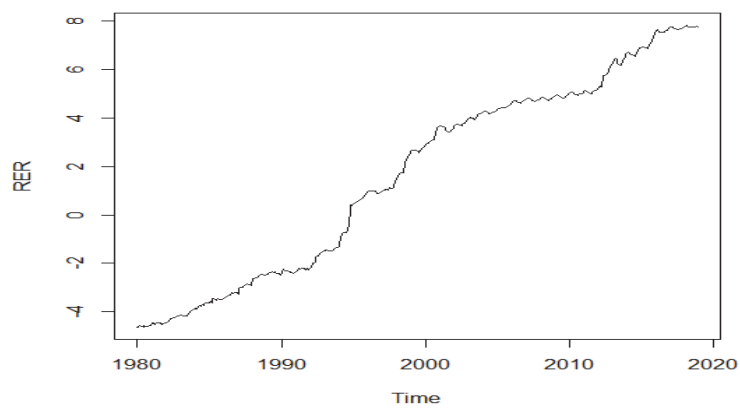

RER of Gabon

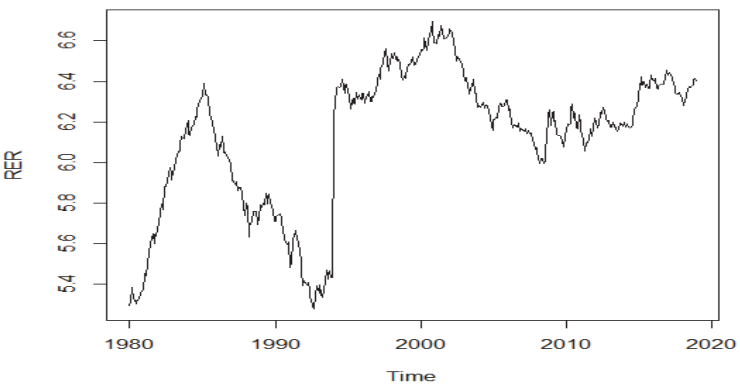

\section{RER of Ghana}

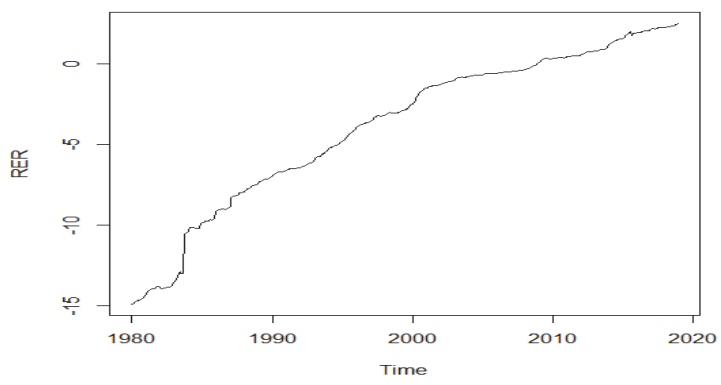

RER of Madagascar

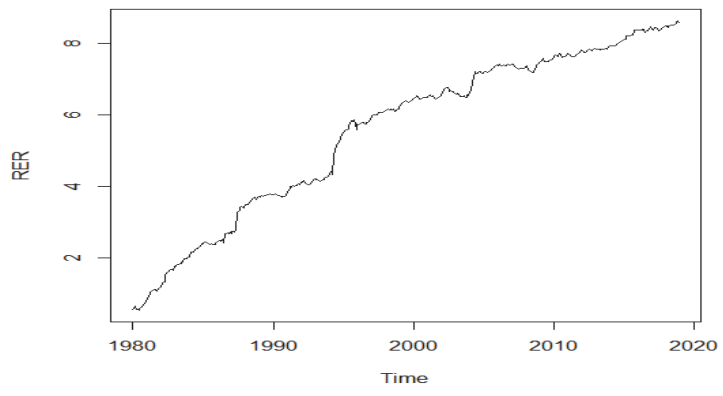

RER of Mauritius

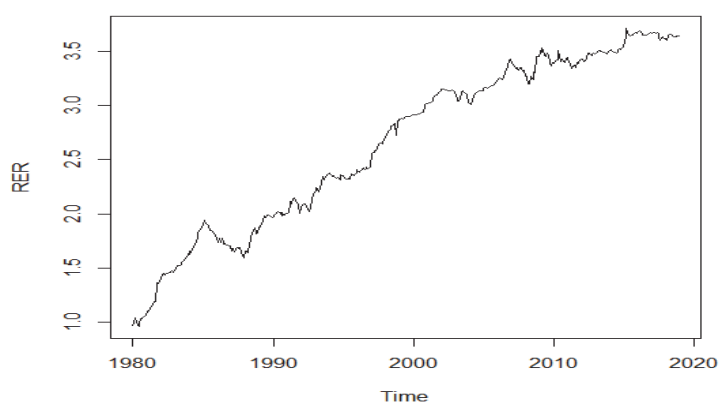


RER of Morocco

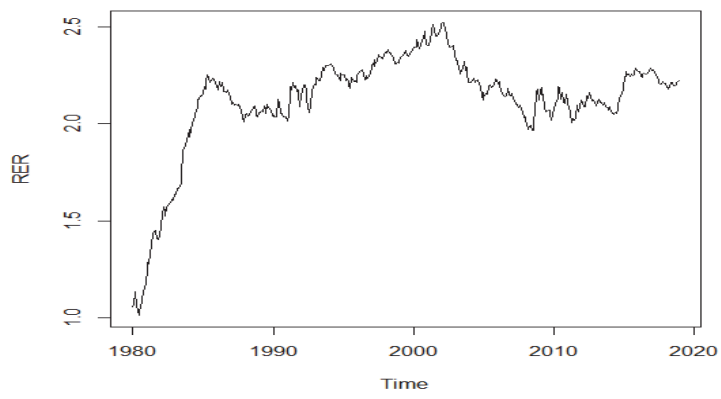

RER of Niger

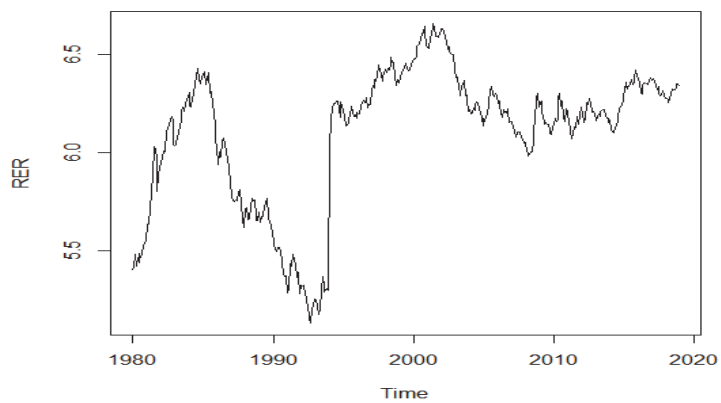

RER of Senegal

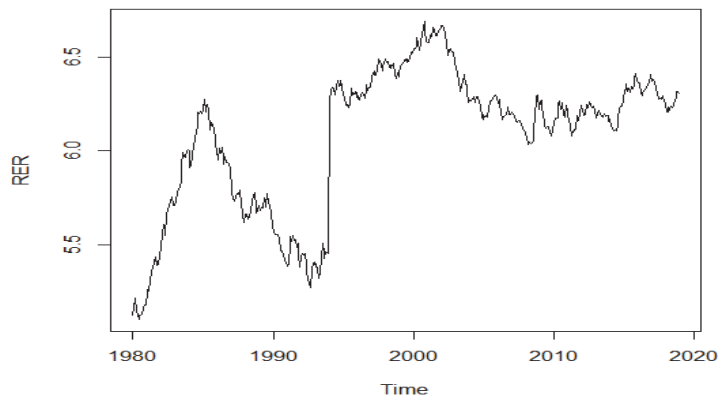

RER of South Africa

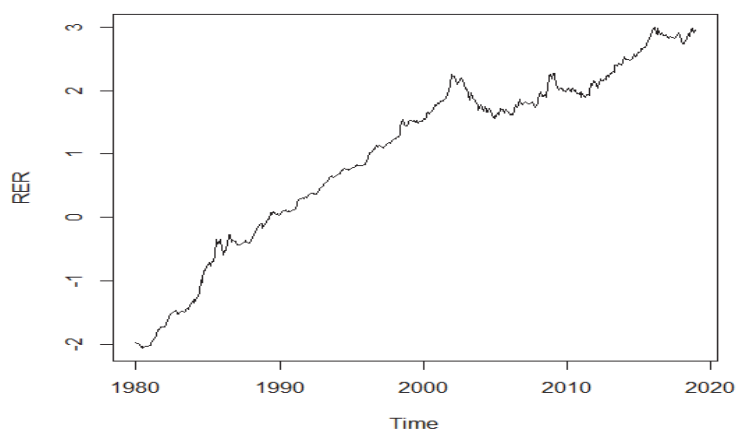

RER of Nigeria

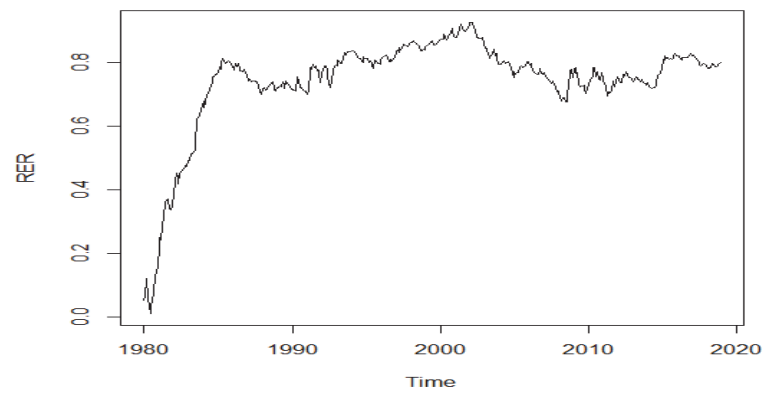

RER of Rwanda

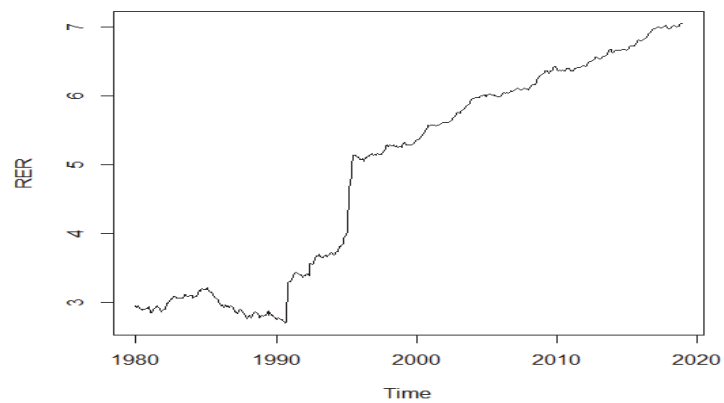

RER of Seychelles

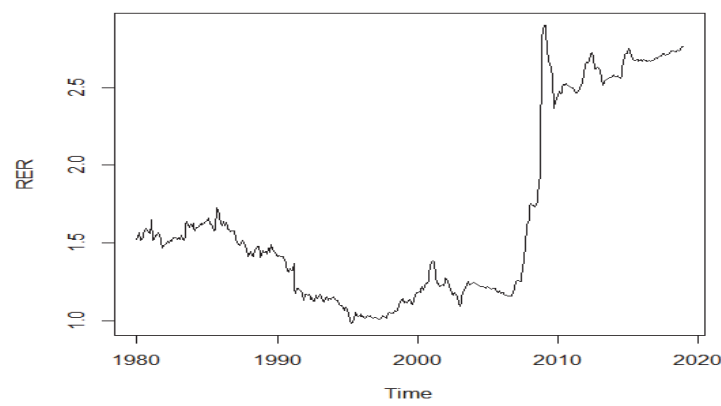

RER of Togo

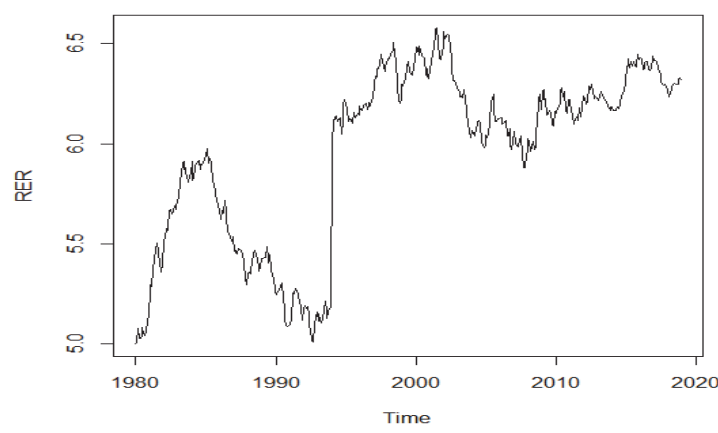


Table 1 reports the summary of descriptive statistics of the data series. The mean returns of the series are predominantly positives, except for Ghana which is negative. Morocco has the smallest standard deviation signifying that it is not as variable relative to Malawi which has the highest standard deviation. The skewness for five countries, namely Botswana, Egypt, Ghana, Malawi and Rwanda are not significant, however, all the kurtosis are significant, which implies that the observations are non-normally distributed. Notice that skewness is mostly negative, apart from Ethiopia, Ghana, Malawi and Seychelles whereas, kurtosis is always positive. The jarque-bera statistics reject the normality test of all the series and at the $1 \%$ significance level.

TABLE 1

\section{SUMMARY STATISTICS OF 468 OBSERVATIONS OF THE RERS OF SOME AFRICAN COUNTRIES}

\begin{tabular}{|c|c|c|c|c|c|c|c|}
\hline Country & Mean & Maximum & Minimum & Std dev. & Skewness & Kurtosis & Jarque-Bera \\
\hline Algeria & 2.8940 & 5.0496 & -0.5374 & 1.9212 & $-0.7025^{\mathrm{a}}$ & $1.7718^{\mathrm{a}}$ & $67.9127^{\mathrm{a}}$ \\
\hline Burkina & 6.0456 & 6.6348 & 5.2095 & 0.3725 & $-0.7815^{\mathrm{a}}$ & $2.4028^{a}$ & $54.5941^{\mathrm{a}}$ \\
\hline Faso & 0.8833 & 2.7369 & -1.2924 & 1.2297 & -0.1591 & $1.7411^{\mathrm{a}}$ & $32.8767^{\mathrm{a}}$ \\
\hline Botswana & 5.9829 & 6.6491 & 4.7495 & 0.4666 & $-0.7928^{a}$ & $2.5327^{\mathrm{a}}$ & $53.2876^{\mathrm{a}}$ \\
\hline Cameroon & 5.9592 & 6.6238 & 4.8802 & 0.4644 & $-0.6291^{\mathrm{a}}$ & $1.9501^{\mathrm{a}}$ & $52.3603^{\mathrm{a}}$ \\
\hline Cote & 0.7965 & 3.8612 & -1.7644 & 1.4667 & -0.1662 & $2.3164^{\mathrm{a}}$ & $11.2664^{\mathrm{a}}$ \\
\hline d'Ivoire & 1.3199 & 4.2507 & -0.4819 & 1.4636 & $0.4212^{b}$ & $2.0433^{\mathrm{a}}$ & $31.6806^{\mathrm{a}}$ \\
\hline Egypt & 6.1256 & 6.6951 & 5.2796 & 0.3458 & $-0.8389^{a}$ & $2.8422^{a}$ & $55.3728^{\mathrm{a}}$ \\
\hline Ethiopia & 2.1091 & 4.2461 & -1.2087 & 1.4897 & $-0.6616^{\mathrm{a}}$ & $2.6321^{\mathrm{a}}$ & $36.7850^{\mathrm{a}}$ \\
\hline Gabon & -1.0275 & 2.6513 & -3.6553 & 2.0055 & 0.1935 & $1.6630^{\mathrm{a}}$ & $37.7800^{\mathrm{a}}$ \\
\hline Gambia & 2.8414 & 5.0933 & -0.6348 & 1.7494 & $-0.5416^{\mathrm{a}}$ & $1.8994^{\mathrm{a}}$ & $46.5027^{\mathrm{a}}$ \\
\hline Ghana & 5.5335 & 8.6137 & 0.5353 & 2.3194 & $-0.5671^{\mathrm{a}}$ & $2.0436^{\mathrm{a}}$ & $42.9192^{\mathrm{a}}$ \\
\hline Kenya & 2.0849 & 7.8289 & -2.6931 & 3.5452 & 0.0177 & $1.5340^{\mathrm{a}}$ & $41.9319^{\mathrm{a}}$ \\
\hline Madagascar & 2.6566 & 3.7123 & 0.9634 & 0.7842 & $-0.3791^{b}$ & $1.8358^{\mathrm{a}}$ & $37.6436^{\mathrm{a}}$ \\
\hline Malawi & 2.1214 & 2.5229 & 1.0125 & 0.2687 & $-2.1484^{\mathrm{a}}$ & $8.2645^{\mathrm{a}}$ & $900.4713^{\mathrm{a}}$ \\
\hline Mauritius & 2.1697 & 6.5280 & -3.1615 & 3.1336 & $-0.3911^{\mathrm{a}}$ & $1.6671^{\mathrm{a}}$ & $46 . .5771^{\mathrm{a}}$ \\
\hline Morocco & 6.0991 & 6.6581 & 5.1300 & 0.3533 & $-1.0412^{\mathrm{a}}$ & $3.2250^{\mathrm{a}}$ & $85.5435^{\mathrm{a}}$ \\
\hline Nigeria & 4.9143 & 7.0426 & 2.6982 & 1.5214 & -0.2271 & $1.4243^{\mathrm{a}}$ & $52.4354^{\mathrm{a}}$ \\
\hline Niger & 6.0761 & 6.6912 & 5.1038 & 0.3796 & $-0.8049^{\mathrm{a}}$ & $2.6698^{a}$ & $52.6589^{a}$ \\
\hline Rwanda & 1.6623 & 2.8988 & 0.9840 & 0.6074 & $0.8213^{\mathrm{a}}$ & $2.0644^{\mathrm{a}}$ & $69.6792^{\mathrm{a}}$ \\
\hline Senegal & 1.2601 & 3.0576 & -1.2245 & 1.1962 & $-0.5171^{\mathrm{a}}$ & $2.1860^{\mathrm{a}}$ & $33.77234^{\mathrm{a}}$ \\
\hline $\begin{array}{l}\text { Seychelles } \\
\text { South Africa } \\
\text { Togo }\end{array}$ & 5.9520 & 6.5768 & 5.0033 & 0.4347 & $-0.7455^{\mathrm{a}}$ & $2.2337^{\mathrm{a}}$ & $54.8016^{\mathrm{a}}$ \\
\hline
\end{tabular}

Note: $\mathrm{a}, \mathrm{b}$ and $\mathrm{c}$ indicate statistical significance at the $1 \%, 5 \%$ and $10 \%$ respectively. The std. dev. denotes the standard deviate

Table 2 presents the results of both linear and nonlinear estimation of the real exchange rates. First, we present the KSS (2003) and Kruse (2011) nonlinear estimation of the real exchange rates. We test the statistical significance of the series using critical values of the KSS (2003) Table 1 demeaned test statistics $-3.48,-2.93$ and -2.66 at $1 \%, 5 \%$ and $10 \%$ significance levels respectively and Kruse (2011) Table 1 demeaned test statistics $13.75,10.17$ and 8.60 at $1 \%, 5 \%$ and $10 \%$ significance levels respectively. Notice here that the KSS (2003) demeaned, 14 out of the 22 countries, statistic values is greater than the critical values so that we do not reject the null hypothesis of a unit root in the series in these African countries. Thus 14 countries are non-stationary. We reject the null hypothesis of a unit root in 8 countries, demonstrating stationarity, hence substantiation of PPP of mean-reverting in real exchange rates. The results of univariate Kruse (2011) statistics test demeaned reject the null hypothesis of a unit 
root in 12 countries, signifying stationarity. Thus proof of a unit root means that the economic shock has a permanent effect of the series. Indicate that the real exchange rates are mean-reverting which makes PPP valid for 12 countries. The results of the ADF unit root test results demonstrate that 2 countries are stationary. The results are not surprising because according to the literature standard ADF test statistics lack power invalidating the PPP. This also supports our assertion that nonlinear such as KSS (2003) and Kruse (2011) performs better compare to linear ADF. In Table 2, Madagascar and Morocco were the only two countries that reject the null hypothesis of a unit root in all three tests of demeaned of KSS (2003) and Kruse (2011), and constant of ADF which makes the PPP valid. The results indicate that 14 series of KSS (2003), 10 series of Kruse (2011) and 20 series of ADF are non-stationary respectively. These results show that the Kruse (2011) unit root test stipulates stronger evidence for validity in the PPP. Both nonlinear tests of KSS (2003) and Kruse (2011) are our preferred choice because they have theoretical and empirical justification and they are more intuitive as they are inferred the speed of mean reversion to deviations.

TABLE 2

KSS, KRUSE AND ADF UNIT ROOT TEST FOR MEAN STATIONERY OF RERS

\begin{tabular}{|c|c|c|c|}
\hline Country & KSS demeaned & KRUSE demeaned & ADF constant \\
\hline Algeria & -1.9567 & $9.0084^{\mathrm{c}}$ & -1.7962 \\
\hline Burkina Faso & $-2.6873^{c}$ & 7.2079 & -2.1256 \\
\hline Botswana & -1.4260 & $15.4635^{\mathrm{a}}$ & -1.2523 \\
\hline Cameroon & -2.4764 & 6.5610 & -2.4867 \\
\hline Cote d'Ivoire & $-2.8984^{c}$ & 8.4901 & -2.1942 \\
\hline Egypt & 0.6578 & $17.0544^{\mathrm{a}}$ & 0.6484 \\
\hline Ethiopia & 1.7617 & $10.0436^{\mathrm{c}}$ & 1.5869 \\
\hline Gabon & $-2.9401^{b}$ & $8.6298^{c}$ & -2.3866 \\
\hline The Gambia & -2.2555 & $11.3173^{\mathrm{b}}$ & -2.1005 \\
\hline Ghana & 2.4817 & $27.1579^{\mathrm{a}}$ & 2.0063 \\
\hline Kenya & -2.3789 & $12.4623^{\mathrm{b}}$ & -2.1693 \\
\hline Madagascar & $-3.4012^{b}$ & $24.2743^{\mathrm{a}}$ & $-3.1824^{b}$ \\
\hline Malawi & 0.4491 & 8.1498 & 0.4574 \\
\hline Mauritius & $-3.1502^{b}$ & $15.6514^{\mathrm{a}}$ & -2.4641 \\
\hline Morocco & $-3.1936^{b}$ & $11.7598^{\mathrm{b}}$ & $-4.8914^{a}$ \\
\hline Nigeria & -0.9078 & 8.5072 & -0.8048 \\
\hline Niger & $-2.7441^{c}$ & 7.7233 & -2.2974 \\
\hline Rwanda & -0.5047 & 5.0903 & -0.4865 \\
\hline Senegal & -2.4645 & 6.1660 & -2.4841 \\
\hline Seychelles & -1.0029 & 1.4403 & -0.2810 \\
\hline South Africa & -2.1623 & $13.0159^{\mathrm{b}}$ & -1.8330 \\
\hline Togo & $-2.8553^{\mathrm{c}}$ & 8.3320 & -2.2188 \\
\hline \# stationary & 8 & 12 & 2 \\
\hline
\end{tabular}

$\mathrm{a}, \mathrm{b}$ and $\mathrm{c}$ indicate statistical significance at the $1 \%, 5 \%$ and $10 \%$ respectively. Critical values of the KSS (2003) demeaned test statistic are $-3.48,-2.93$ and -2.66 at $1 \%, 5 \%$ and $10 \%$ significance levels respectively. Critical values of the Kruse (2011) demeaned test statistic are 13.75, 10.17 and 8.60 at 1\%,5\% and 10\% significance levels respectively. Critical values of the ADF test statistic based on MacKinnon (1996) one-sided p-values are -3.4599, -2.8744 and -2.5737 at $1 \%, 5 \%$ and $10 \%$ significance levels respectively. 
Table 3 shows the de-trended of KSS (2003) and Kruse (2011) and constant and trend of ADF. Again, we test the statistical significance of the series making use of the critical values of KSS (2003) Table 1 de-trended test statistics $-3.93,-3.40$ and -3.13 at $1 \%, 5 \%$ and $10 \%$ significance levels respectively and critical values of Kruse (2011) Table 1 de-trended test statistics 17.10, 12.82 and 11.10 at 1\%, 5\% and $10 \%$ significance levels respectively. KSS (2003) de-trended cannot reject the null hypothesis of a unit root in all countries, except Ghana which is significant, hence 21 countries are non-stationary. As with Kruse (2011) de-trended, the real exchange rates of Ghana is statistically significant. This implies that the series is stationary in only 1 country, whilst 21 countries are non-stationary. Likewise, constant and trend of ADF test statistics, 21 countries were non-stationary, but only Morocco is statistically significant at 5\% level. These results of univariate tests suggest that the series are predominately non-stationary. In Table 3 , Ghana is the only country that is significant across the two test statistics of KSS (2003 and Kruse (2011) which makes PPP valid.

TABLE 3

KSS, KRUSE, AND ADF UNIT ROOT TEST FOR TREND STATIONERY OF RERS

\begin{tabular}{|l|l|l|l|}
\hline Country & KSS de-trended & KRUSE de-trended & ADF constant, trend \\
\hline Algeria & -0.5674 & 0.3263 & -0.2531 \\
Burkina Faso & -2.6570 & 7.5873 & -2.1078 \\
Botswana & -1.6390 & 2.8536 & -1.5572 \\
Cameroon & -2.5346 & 8.9394 & -2.2070 \\
Cote d'Ivoire & -2.3179 & 8.2111 & -2.0059 \\
Egypt & -0.6105 & 1.4398 & -0.9104 \\
Ethiopia & -1.8348 & 3.3973 & -1.8386 \\
Gabon & -3.0200 & 9.5508 & -2.2520 \\
The Gambia & -1.6490 & 2.8087 & -2.0087 \\
Ghana & $-3.4369^{\mathrm{b}}$ & $15.3720^{\mathrm{b}}$ & -2.9326 \\
Kenya & -1.7059 & 2.9526 & -1.0815 \\
Madagascar & -1.5117 & 2.3639 & -1.4030 \\
Malawi & -2.1564 & 2.2591 & -2.1907 \\
Mauritius & -1.5626 & 8.7018 & -1.9001 \\
Morocco & -2.9112 & 1.6880 & $-3.9195^{\mathrm{b}}$ \\
Nigeria & -1.3002 & 7.9170 & -1.0003 \\
Niger & -2.8093 & 9.2530 & -2.2814 \\
Rwanda & -2.9414 & 8.9034 & -1.9841 \\
Senegal & -2.7549 & 7.9527 & -2.2482 \\
Seychelles & -2.1562 & 3.0662 & -1.4290 \\
South Africa & -1.5522 & 8.8542 & -1.6180 \\
Togo & -2.9585 & 1 & -2.3697 \\
\# stationary & 1 & $5 \%$ & 1 \\
\hline
\end{tabular}

$\mathrm{a}, \mathrm{b}$ and $\mathrm{c}$ indicate statistical significance at the $1 \%, 5 \%$ and $10 \%$ respectively. Critical values of the KSS (2003) detrended test statistic are $-3.93,-3.40$ and -3.13 at $1 \%, 5 \%$ and $10 \%$ significance levels respectively. Critical values of the Kruse (2011) de-trended test statistic are 17.10, 12.82 and 11.10 at $1 \%, 5 \%$ and $10 \%$ significance levels respectively. Critical values of the ADF test statistic based on MacKinnon (1996) one-sided p-values are -3.9779, -3.4195 and -3.1323 at $1 \%, 5 \%$ and $10 \%$ significance levels respectively. 
One factor supports the rationale of these results. The main reason is that each of these tests has its challenges; the critical values of demeaned and constant tests were lower than the critical values of detrended and constant and trend tests, hence, which might produce different statistical significance. The results show that 14 series of KSS (2003) demeaned, 10 series of Kruse (2011) demeaned, and 20 series of ADF constant are non-stationary. Similarly, when de-trended and constant and trend test was run, 21 series each of the KSS (2003), Kruse (2011) and ADF are non-stationary respectively. Therefore, we can say on the authority that real exchange rates are non-stationary in these African countries.

An alternative method is to check the long-run PPP hypothesis is to conduct the cointegration test of the nominal exchange rates and the foreign and domestic price levels. Nevertheless, the nominal exchange rates might in no way the case signify the price differences in the short run. The well-known procedure to check for cointegration is the Engle and Granger (1987) approach. However, when dealing with more than one cointegrating vector, the Johansen $(1988,1990)$ approach is believed to be suitable. The Johansen approaches permit one to test for the existence of multiple cointegrations. Since the economic time series are nonstationary processes, we used the VAR framework estimated in the first differenced form with lag intervals 1 to 3 . We use Johansen $(1988,1990)$ multivariate cointegration method to test whether the series has long-run association ship. Johansen's cointegration test reveals that it is possible to reject the null hypothesis of no cointegration vector for Gabon, Gambia, Ghana, Kenya, Madagascar, Malawi, Mauritius, Morocco, South Africa and Togo. This means that the hypothesis of no cointegrating vector is rejected at the $1 \%$ and $5 \%$ levels of statistical significance for Gabon, Gambia, Ghana, Kenya, Madagascar, Malawi, Mauritius, Morocco, South Africa and Togo based on trace statistic test and maximum eigenvalue test (see Doganlar et al. 2009). This implies that the nominal exchange rate and foreign and domestic price levels for Gabon, Gambia, Ghana, Kenya, Madagascar, Malawi, Mauritius, Morocco, South Africa and Togo are cointegrated once Johansen's maximum likelihood is applied. Thus, the nominal exchange rate and price levels in these 10 countries, in the long run, move together.

The Johansen's test indicates that the null hypothesis of no cointegrating vectors cannot be rejected for Burkina Faso, Botswana, Cote d'Ivoire, Egypt, Nigeria, Niger, Rwanda, Senegal and Seychelles at the $1 \%$ and $5 \%$ levels of statistical significance for trace statistic and maximum eigenvalue tests. We can categorically say that PPP has normally failed.

The Johansen's test shows the null hypothesis of no cointegrating vector is rejected for Cameroon and Ethiopia at the $1 \%$ and $5 \%$ statistical significance levels for trace statistic test. In the same vein, we cannot find any cointegration vectors for these two countries; namely Cameroon and Ethiopia for maximum eigenvalue test. Similarly, the null hypothesis of no cointegrating vectors is rejected for Algeria at 5\% statistical significance levels for maximum eigenvalue test. Nevertheless, the null hypothesis of no cointegrating vectors cannot be rejected for Algeria based on trace statistic test.

The overall conclusion based on Johansen's cointegration test indicates that 12 countries in the study, it is hard to find cointegration vectors between nominal exchange rates and foreign and domestic price levels. The result implies that deviations from PPP for 12 of 22 each of the individual country are persistent. The results of this study are similar to the empirical result provided by Salehizadeh and Taylor (1999) and Taylar and Taylor (2004). 
TABLE 4

RESULTS OF JOHANSEN COINTEGRATION TESTS OF SOME AFRICAN COUNTRIES

\begin{tabular}{|c|c|c|c|c|}
\hline Country & Lag & Hypothesized no. of CE (s) & Trace statistic & Max-Eigen value statistic \\
\hline \multirow[t]{3}{*}{ Algeria } & & None & 27.9676 & $23.9826^{\mathrm{b}}$ \\
\hline & 3 & At most 1 & 3.9850 & 2.6681 \\
\hline & & At most 2 & 1.3170 & 1.3170 \\
\hline \multirow[t]{3}{*}{ Burkina Faso } & 3 & None & 22.8429 & 14.4108 \\
\hline & & At most 1 & 8.4321 & 6.6897 \\
\hline & & At most 2 & 1.7424 & 1.7424 \\
\hline \multirow[t]{3}{*}{ Botswana } & 3 & None & 22.4916 & 15.6794 \\
\hline & & At most 1 & 6.8122 & 5.7801 \\
\hline & & At most 2 & 1.0321 & 1.0321 \\
\hline \multirow[t]{3}{*}{ Cameroon } & 3 & None & $29.8565^{\mathrm{b}}$ & 20.2984 \\
\hline & & At most 1 & 9.5581 & 9.5410 \\
\hline & & At most 2 & 0.0170 & 0.0170 \\
\hline \multirow[t]{3}{*}{ Cote d'Ivoire } & 3 & None & 26.8194 & 18.8207 \\
\hline & & At most 1 & 7.9987 & 7.6651 \\
\hline & & At most 2 & 0.3335 & 0.3335 \\
\hline \multirow[t]{3}{*}{ Egypt } & 3 & None & 29.2210 & 19.4332 \\
\hline & & At most 1 & 9.7878 & 9.4666 \\
\hline & & At most 2 & 0.3212 & 0.3212 \\
\hline \multirow[t]{3}{*}{ Ethiopia } & 3 & None & $32.7859^{\mathrm{b}}$ & 18.3863 \\
\hline & & At most 1 & 14.3995 & 14.3825 \\
\hline & & At most 2 & 0.0170 & 0.0170 \\
\hline \multirow[t]{3}{*}{ Gabon } & 3 & None & $29.9855^{b}$ & $21.5322^{\mathrm{b}}$ \\
\hline & & At most 1 & 8.4532 & 7.9774 \\
\hline & & At most 2 & 0.4758 & 0.4758 \\
\hline \multirow[t]{3}{*}{ Gambia } & 3 & None & $31.7746^{\mathrm{b}}$ & $25.2073^{b}$ \\
\hline & & At most 1 & 6.5673 & 5.0230 \\
\hline & & At most 2 & 1.5442 & 1.5442 \\
\hline \multirow[t]{3}{*}{ Ghana } & 3 & None & $46.3239^{a}$ & $27.0684^{\mathrm{a}}$ \\
\hline & & At most 1 & 19.2555 & 16.6085 \\
\hline & & At most 2 & 2.6470 & 2.6470 \\
\hline \multirow[t]{3}{*}{ Kenya } & 3 & None & $51.0435^{\mathrm{a}}$ & $27.4201^{\mathrm{a}}$ \\
\hline & & At most 1 & 23.6233 & 18.4437 \\
\hline & & At most 2 & 5.1796 & 5.1796 \\
\hline \multirow[t]{3}{*}{ Madagascar } & 3 & None & $37.2700^{\mathrm{a}}$ & $23.3962^{\mathrm{b}}$ \\
\hline & & At most 1 & 13.8738 & 10.6003 \\
\hline & & At most 2 & 3.2734 & 3.2734 \\
\hline \multirow[t]{3}{*}{ Malawi } & 3 & None & $33.9006^{\mathrm{b}}$ & $28.1565^{\mathrm{a}}$ \\
\hline & & At most 1 & 5.7441 & 4.8838 \\
\hline & & At most 2 & 0.8603 & 0.8603 \\
\hline \multirow[t]{3}{*}{ Mauritius } & 3 & None & $43.9752^{\mathrm{a}}$ & $25.4081^{b}$ \\
\hline & & At most 1 & 18.5671 & 14.2322 \\
\hline & & At most 2 & 4.3349 & 4.3349 \\
\hline \multirow[t]{3}{*}{ Morocco } & 3 & None & $39.4927^{\mathrm{a}}$ & $26.2494^{\mathrm{a}}$ \\
\hline & & At most 1 & 13.2433 & 7.9338 \\
\hline & & At most 2 & 5.3095 & 5.3095 \\
\hline \multirow[t]{2}{*}{ Nigeria } & 3 & None & 23.8175 & 16.6050 \\
\hline & & At most 1 & 7.2125 & 6.4389 \\
\hline
\end{tabular}




\begin{tabular}{|c|c|c|c|c|}
\hline Country & Lag & Hypothesized no. of CE (s) & Trace statistic & Max-Eigen value statistic \\
\hline \multirow{4}{*}{ Niger } & \multirow{4}{*}{3} & At most 2 & 0.7736 & 0.7736 \\
\hline & & None & 18.8456 & 10.2793 \\
\hline & & At most 1 & 8.5662 & 7.4174 \\
\hline & & At most 2 & 1.1488 & 1.1488 \\
\hline \multirow[t]{3}{*}{ Rwanda } & \multirow[t]{3}{*}{3} & None & 17.3932 & 11.0464 \\
\hline & & At most 1 & 6.3467 & 5.0657 \\
\hline & & At most 2 & 1.2811 & 1.2811 \\
\hline \multirow[t]{3}{*}{ Senegal } & \multirow[t]{3}{*}{3} & None & 16.9190 & 8.9237 \\
\hline & & At most 1 & 7.9952 & 7.7268 \\
\hline & & At most 2 & 0.2684 & 0.2684 \\
\hline \multirow[t]{3}{*}{ Seychelles } & \multirow[t]{3}{*}{3} & None & 15.4444 & 8.4284 \\
\hline & & At most 1 & 7.0159 & 6.6813 \\
\hline & & At most 2 & 0.3346 & 0.3346 \\
\hline \multirow[t]{3}{*}{ South Africa } & \multirow[t]{3}{*}{3} & None & $33.2745^{\mathrm{b}}$ & $21.9440^{\mathrm{b}}$ \\
\hline & & At most 1 & 11.3305 & 7.5119 \\
\hline & & At most 2 & 3.8186 & 3.8186 \\
\hline \multirow[t]{3}{*}{ Togo } & \multirow[t]{3}{*}{3} & None & $48.5081^{\mathrm{a}}$ & $27.5586^{\mathrm{a}}$ \\
\hline & & At most 1 & 20.9496 & 19.8789 \\
\hline & & At most 2 & 1.0706 & 1.0706 \\
\hline
\end{tabular}

Critical values for the trace statistic test are 29.80 and 35.65 at $5 \%$ and $1 \%$ significance levels respectively. Critical values for max-eigen statistic test are 21.13 and 25.52 at $5 \%$ and $1 \%$ significance levels respectively. $\mathrm{b}$ denotes rejection of the hypothesis at the $5 \%$ level.

a denotes rejection of the hypothesis at the $1 \%$ level.

\section{CONCLUSION}

We investigate further whether the PPP holds between the US and some African countries. We employed the nonlinear unit root test due to Kapetanios et al. (2003) and Kruse (2011) in a time series against nonlinear but globally stationary exponential smooth transitions autoregressive (ESTAR) process and standard linear ADF test. The both linear and nonlinear appear to advocate that most of the series fail to reject the null hypothesis of a unit root in the series at conventional significance levels The results seem to suggest that real exchange rates are non-stationary in these African countries when demeaned and constant, and de-trended and constant and trend were run. The overall conclusion based on Johansen's cointegration test indicates that 12 countries in the study, it is hard to find cointegration vectors between nominal exchange rates and foreign and domestic price levels. We can categorically say that PPP has normally failed. Pentecost (2004) gave accounts for the failure of PPP. These results have policy implications for international finance, policymakers and empirical researchers. 


\section{REFERENCES}

Abadir, K.M., \& Distaso, W. (2007). Testing joint hypotheses when one of the alternatives is one-sided. Journal of Econometrics, 140, 695-718.

Akinboade, O. A., \& Makina, D. (2006). Mean reversion and structural breaks in real exchange rates: South African evidence. Applied Financial Economics, 16(4), 347-358.

Arize, A. C., John, M., \& Kiseok, N. (2010). Co-integration, dynamic structure and the validity of purchasing power parity in African countries. International Review of Economics and Finance, 19, 755-768.

Chang, T., Chia-Hao, L., \& Pei-I, C. (2012). Nonlinear adjustment to purchasing power parity in G-7 countries. Applied Economics Letter, 19, 123-128.

Cheung, Y-W., Kon, S. L., \& Michael, B. (2004). Dissecting the purchasing power parity puzzle: The unconventional roles of the nominal exchange rate and price adjustment. Journal of International Economics, 64, 135-150.

Christopoulos, D. K., \& Leon-Ledesma, M. A. (2010). Smooth breaks and non-linear mean reversion: Post-Bretton Woods real exchange rates. Journal of International Money and Finance, 29(6), 1076-1093.

Doganlar, M., Bal, H., \& Özmen, M. (2009). Testing long-run validity of purchasing power parity for selected emerging market economies. Applied Economics Letters, 16(14), 1443-1448.

Granger, C. W. J., \& Terasvirta, T. (1993). Modelling nonlinear economic relationships. Oxford University Press, New York.

Hamilton, J.D. (1994). Time series analysis. Princeton: Princeton University Press.

He, H., Chou, M., \& Chang, T. (2014). Purchasing power parity for 15 Latin American countries: Panel SURKSS test with a Fourier function. Economic Modelling, 36, 37-43.

Holmes, M. J. (2001). New evidence on real exchange rate stationarity and purchasing power purity in less developed countries. Journal of Macroeconomics, 23(4), 601-614.

Kapetanios, G., Shin, Y., \& Snell, A. (2003). Testing for a unit root in the nonlinear STAR Framework. Journal of Econometrics, 112, 359 - 379.

Krogbo, J. M. (2006). Purchasing power parity and real exchange rate behaviour in Africa. Applied Financial Economics, 16(1), 169-183.

Kruse, R. (2011). A new unit root test against ESTAR based on a class of modified statistics. Statistical Papers, 52(1), 71-85.

Lothian, J. R. \& Taylor, M. P. (2008). Real exchange rates over the past two centuries: How important is the Harrod-Balassa-Samuelson effect? Economic Journal, 118, 1742-1763.

Michael, P., Nobay, R.A., \& Peel, D.A. (1997). Transactions costs and nonlinear adjustment in real exchange rates: an empirical investigation. Journal of Political Economy, 105, 862-879.

Pentecost, E. J. (1993). Exchange rate dynamics. Cambridge: Edward Elgar.

Salehizadeh, M., \& Taylor, R. (1999). A test of purchasing power parity for emerging economies. Journal of International Financial Markets, Institutions and Money, 9, 183-193.

Sarno, L. (2005). Viewpoint towards a solution to the puzzle in exchange rate economics: where do we stand? Journal of Economics, 38(3), 673-708.

Sarno, L., \& Taylor, M., P. (2002). The economics of exchange rates. Cambridge University Press, Cambridge.

Su, C-W., Chang, T., \& Liu, Y-S. (2012). Revisiting purchasing power parity for African countries: with nonlinear panel unit-root tests. Applied Economics, 44, 3263 - 3273.

Taylor, A. M., \& Taylor, M. P. (2004). The purchasing power parity debate. Journal of Economic Perspectives, 18, 135-158.

Yilanci, V., Aslan, M., \& Ozgur., O. (2017). Testing the validity of purchasing power parity theory for African countries. Applied Economics Letters, 25(18), 1273-1277.

102 Journal of Applied Business and Economics Vol. 21(7) 2019 
Yilanci, V., \& Eris, Z. A. (2013). Purchasing power parity in African countries: further evidence from Fourier unit root tests based on linear and nonlinear models. South Africa Journal of Economics, 81(1), 20-34

Zehirun, M. F., Breitenbach, M. C., \& Kemegue, F. (2015). Assessment of monetary union in South African Development Community: Evidence from cointegration and panel unit root tests. Working Paper. 